\title{
A Study of Investment Behaviour about Middle-Class Group Families towards Different Types of Opportunities
}

\author{
Riyazuddin \\ Department of Commerce E Business Administration, C.C.S. University, Meerut, India \\ Email Id: profriyazuddin@gmail.com
}

\begin{abstract}
Economy of our country is increasing rapidly among the countries of world where 1.3 Billion people and middle group covers $45 \%$ of the population. The remaining 59\% people come under poor category and 1\% in rich category. The middle group is divided into lower and higher. Lower middle group family income is less than 25000 per month and the upper middle class earn $50 k$ to $150 k$ monthly (As on 2018-19). Middle group population is the vital component for Indian economic development. They effect demand and supply of need and comfort products at a great extent. Their saving and investment shape gets influenced by their predicted needs for future; provide extensive scope for researchers due to larger impact on the investment bazaar. Through this research paper, researcher throws the light on investment behaviour adopted by middle group families, included groups associated in either service or business, whose income exist between two lakhs to five lakhs p.a. main purpose of selecting certain income group is to know that how to manage their investment avenues with small or limited income after spend their all expense. The reason of this study is to find out answer of some genuine questions for their choices of investment's instruments in money market and capital market, real estate, commodity market, derivatives market etc., investment pattern implemented in a definite manner and objectives behind selecting a certain investment's instrument. Investment is one the main key issue for middle group families as they have small saving today are to meet their needs for future expenses. As a conclusion, this research paper study helps to examine that how they manage their savings and expenses, risk facing capacity and other elements which influence their investment decision.
\end{abstract}

Keywords: Income, Commodity Market, Money Market \& Capital Market, Real Estate.

\section{PAPER/ARTICLE INFO RECEIVED ON: 01/04/2020 ACCEPTED ON: 22/05/2020}

Reference to this paper should be made as follows:

Riyazuddin (2020), “A Study of Investment Behaviour in relation to Middle Class Group Families towards Different Types of Opportunities", Int. J. of Trade and Commerce-IIARTC, Vol. 9, No. 1, pp. $128-138$ 


\section{INTRODUCTION}

Logically, an investment is an asset or item acquired to generate income or appreciation. In another term-an investment is a future agreement of the current outflow of money for the next inflow of return after some specified period. In the sense of economic, if Investment is the procure of commodities that are not consumed today, but may be used in the future to generate wealth. In finance, an investment is a monetary asset purchased with the idea that the asset will provide income in the future or will later be sold at a higher price for a profit. An investment in today's assurance of money for a specific duration to grow future payments that will refund anticipated inflate rate, the improbability of the next amount, and the time the funds are delivered. Above definitions include three dimensions to Investment; the following diagram shows the investment process for generating gain:

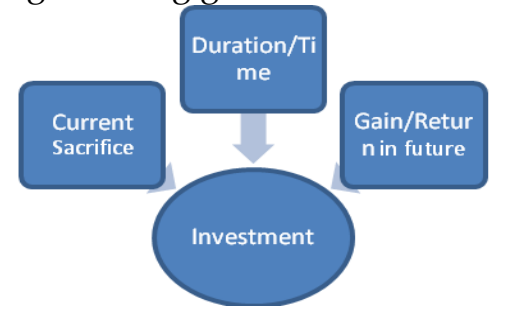

Source: Self Prepared

Figure: 1 Dimension in Investment

\section{Investment Alternatives}

There is a verity of investment instruments available in financial markets; some of these are marketable and liquid able. In contrast, others are non-marketable, and some of these are classified into highly risky, moderate risk, or low risk. Investors can select a suitable any one instrument or more depending on their priority, risk bearable condition, needs, and future gains. Investment alternatives can affect categories broadly under the following heads

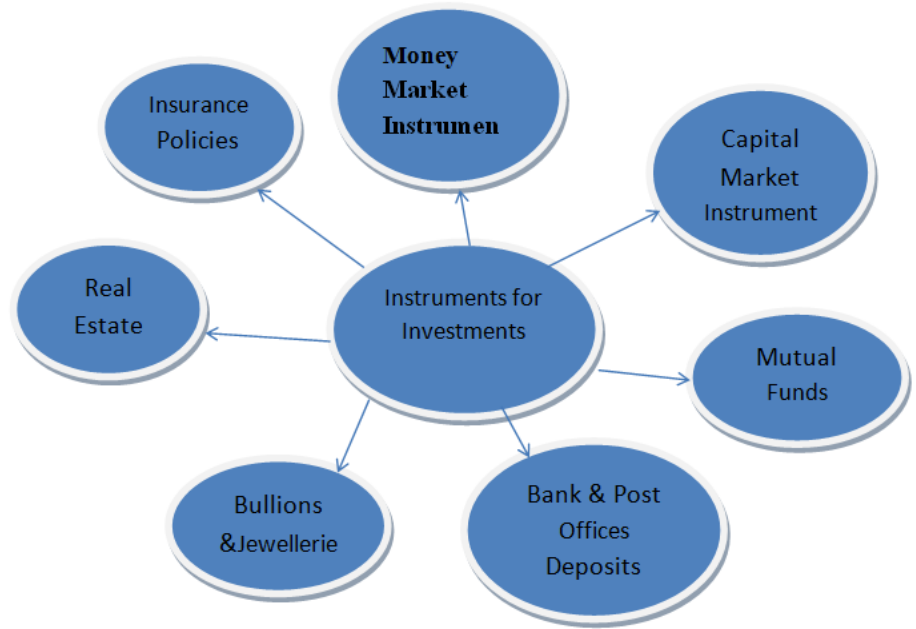

Figure: 2 Instruments for Investments

Various Kinds of Investment Avenue,

Source: Self Prepared 


\section{Investment alternatives in India}

\section{Financial Investment}

Non Marketable Financial Instruments

Marketable Financial Instruments

2. Real Investment

- Non-marketable financial instruments: Following are the financial instrument which provides a moderately high return, but there is a restriction on trading in the market.

* Company F.D.s

* Public Provident Fund

* Bank Deposits

* Post Office Schemes

- Equity shares: Equity shares can be traded in the financial market on the secondary level. Investors can get the benefit due to the fluctuations in the price of share and dividend rendered by companies. An equity shareholder has ownership in the company. These shares can be classified into following broad categories as per the stock market:

* Growth shares-These types of shares generally do not pay dividends, as the companies seriously wish to re-invest any earnings to accelerate growth in the short term.

* Blue-chip shares- Shares of large, well-recognized, financially stable organization with an impressive record of earnings and dividends.

- Bonds: Bonds are known for safe zone Investment Avenue. Different kinds of relationships are given below:

* Government Security (G sec bonds)

* GOI relief funds

* Govt. agency funds

* Public sector undertakings (PSU Bonds)

* RBI Bond

* Debenture of private sector co.

- Money market instrument: It is used for short-term needs for the company. These instruments are those instruments, which have less than one year maturity period.

* Treasury-Bills

* Commercial Paper

* Certificate of Deposit

- Mutual Funds- A mutual fund is a reliance that pools together the savings of several investors who share the same financial aim. The fund managers do invest this pool of money in financial instruments of schemes. The different kinds of projects are given below:

* Balanced Funds

* Sector Fund

* Index Funds

* Equity Oriented Funds

- Life insurance: Today, life insurance has become a vital investment avenue. Various schemes are available in this sector for a certain sum and other benefits. Followings schemes are given below: 
* Endowment assurance policy

* Whole life policy

* Money back policy

* Term assurance policy

- Real estate: This is also the most crucial portfolio for investors in a residential house. It is also the significant assets in the selection of investors is a residential house. In addition to a residential home, the investments can be made in the following types of real estate:

* Agricultural land

* Semi-urban land

* Farm House/Flats

- Commodity Instruments: Investors can also invest in the following instruments:

* Silver

* Gold

* Precious stones

* Crops

- Financial Derivatives: These are such instruments of finance that derive their value from some underlying assets or instruments. The following types of devices for derivative can be used:

* Options

* Futures

* Swap

II. Process of Investment

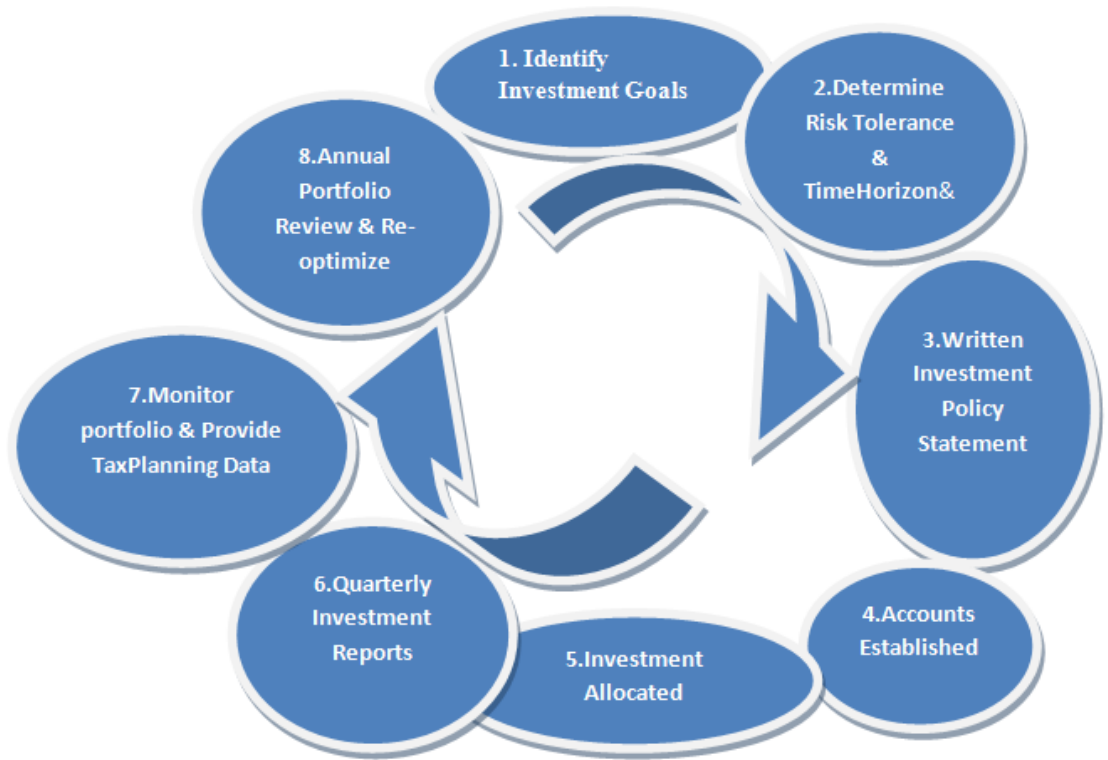

Figure: 3 A Study of Investment Behaviour of Middle Income Group towards Different Kinds of Investment Avenues

$-131-$ 
A Study of Investment Behaviour in relation to Middle Class Group Families towards Different Types of Opportunities Riyazuddin

\section{Identify1.}

\section{Status of Middle Income Group}

According to a 2017 report by McKinsey World Institute (MGI), Indian households are classified into five economic teams supported by annual income. These are: underprivileged (less than government agency ninety,000 or but USD one,11969), Aspirers (INR ninety,000 government agency ), Seekers (INR two hundred,000 - government agency five hundred,000 or USD four,376 - \$10,941), Strivers (Rs. 500,000 - government agency one million or \$ ten,941 - \$ 21,882 ) and therefore the world Indians (more than government agency one million or quite $\$$ twenty-one,882). The National Council for Applied Economic analy sis (NCAER) categorizes the middle-Groupon the idea of the annual financial gain of Indian households between Rs. 340,000 to Rs. 1.7 million. The present position of middle-group houses in Bharat is thirty-one .4 million, which interprets into a hundred and sixty million folks. The NCAER gave a current report that renders the suggestions that the country can house fifty-three .3 million middlegroup households, i.e., around 267 million people during this category by 2015-16. Further, the middle-group population is anticipated to succeed in 547 million by 2025. A typical Indian materialistic unit spends concerning fifty \% of the entire financial gain on daily expenses, and therefore, the rest is saved [3]. As per the report of times of Bharat (July five, 2019), of 218 economies, eighty square measure within the high-income cluster, sixty within the uppermiddle, forty-seven within the lower-middle, and thirty-one within the low-income group. The classification is updated on the first day of July once a year. Richest $100 \%$ of Bharatns own over $3 / 4$ of wealth in India. The wealthiest $100 \%$ of Indians own seventy seven. $\%$ of the country's wealth, says credit Svizzera in their 2018 world Wealth Report. The lowest hour, the bulk of the population, down $4.7 \%$. The wealthiest 1 Chronicles own fifty-one $.5 \%$. India doesn't have a middle-income lure drawback. It's a retardant of wooly thinking on the policy. Bharat wants deep reforms and steady growth to even get into the higher middle-income class, which is wherever the middle-income lure drawback generally arises. Finally, a lure of Our Own India may be a low middle-income country with a GNI per capita of around $\$ 2,000$. Albeit Bharat reaches \$5 trillion in the gross domestic product by 2024-25 - Govt. of Bharat explicit and commendable objective - it'll still be a lower-middle-income country. Finance Minister Nirmala Sitharaman has aforesaid that \$5 trillion gross domestic product is merely AN intermediate goal - on the thanks to probably changing into a \$9-10 trillion economy, at that purpose India's GNI per capita is going to be around \$6,000, on the point of wherever Thailand is nowadays and far below today's China or Malaya. At that stage, we tend to might ought to worry concerning the middle-income lure. For now, our challenge is to avoid the muddledpolicy lure we tend to appear to be stepping into to succeed in $\$ 5$ trillion. 


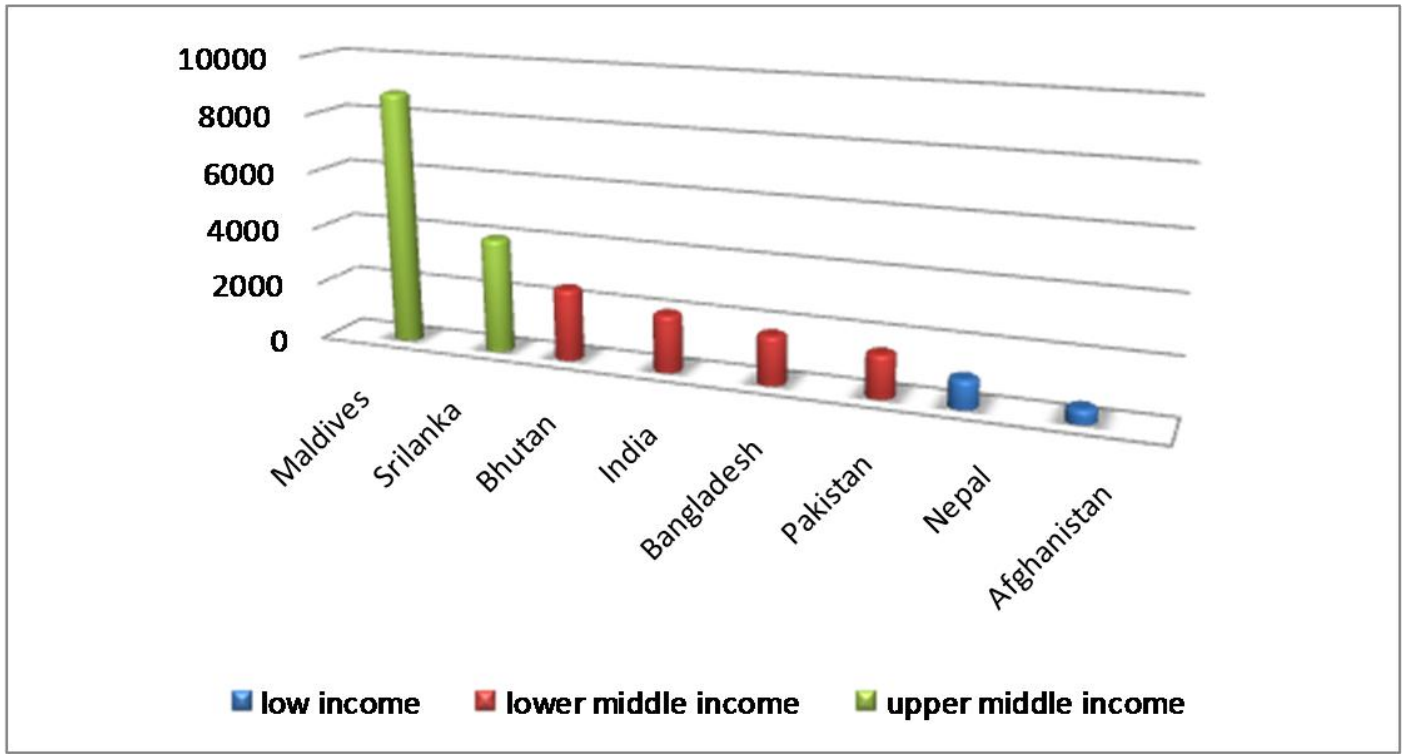

Figure: 4 Classification of South Asian Countries By Income Levels, 2019-20. Source: Self Prepared

\section{REVIEW OF LITERATURE}

Khare and Chaturvedi (2012), there are two main phases of Investment's preference and pattern. Gain is likely expected in the future, which is uncertain. In a few investments, i.e., stocks options or security options, where risk is a dominant attribute while in government's securities, time is a dominant attribute like govt. Bonds. Various factors are there, which affect investor's portfolios, such as annual income, government policy, economic deviations, natural disasters, etc.

Dr. Vanita Tripathi (TAXMANN, December-2015), A text Book Security Analysis \& Portfolio Management stating as Investment is considering that it is a rational decision-making process where an investor tries with the hopping for better return reducing risk. There are many investment tools available such as equity share market, bills, mutual funds, derivatives, realestate, etc. instead of making Investment all money in one device, the investor should spread out his wealth in various securities to avoid maximum risk.

Kaur and Sharma (S. Chand-2019), A book Fundamentals of Investment focusing the various types of investment avenues for the mind-set of fixed income with nil risk and profit with moderate or high risk. It also depicts the real picture of traditional and trend investment avenues in the financial market.

Niranjan and Hosamane (2010). Knowing the behavior of Investment provides a vital perception of the process of economic development. Economic growth unfavorably depends on capital accumulation, and it stems from Investment. The economy's productive capacity can be expanded by investment outlay as a vibrant variable on long-life capital goods that represent technical advance. 
A Study of Investment Behaviour in relation to Middle Class Group Families towards Different Types of Opportunities Riyazuddin

3. Problem/Objectives of The Study

a. To make a study, the investment priority amongst people comes in seekers (annual disposable income- INR 200,000 - INR 500,000) economic group.

b. To make examines the management and risk-bearing capacity between expenses and saving and other elements that affect their outlay decision.

c. To know the perception and behavior of investors towards different- different investment tools.

\section{Research Methodology}

Research methodology for the proposed research is the following:

1. Type of Research-This research is based on descriptive.

2. Definition of the Population - The study narrates to the investment shapes of included both groups involved in either business or service, whose per annum disposable income lies between INR 2,50,000 to INR 5,00,000.

3. Sample Size- The sample size of 150 respondents was taken for the research work among in Greater Noida, U.P. This sample will be measured suitable to represent the features of the entire population.

4. Sampling Procedure - The sampling procedure followed in this study is non-probability suitable sampling

5. Primary Data- The primary data were collected through a well-structured questionnaire using the survey method.

6. Secondary Data- Referred investment management textbooks, websites, newspapers, magazines, research papers, and journals.

7. Analysis of Data - The collected data were used to analyze, Simple percentage analysis tools were used to calculate the same. It tells the frequency of the respondents' attitude, profile, and income opinion regarding different variables. The calculated and analyzed data is shown systematically by using various tools.

5. Results AND Discussion

1. Investor Choice for the investment avenues: Table1.provide the information about the preference of sample investors in percentage towards various investment products as bank deposits, insurance schemes, share market, real estate, and billions, etc.

Table 1: Investor Preferences for Investment Avenues Respondents investing in various avenues

\begin{tabular}{|c|l|c|c|}
\hline S.No. & \multicolumn{1}{|c|}{ Investment Avenues } & Respondents & Percentage \\
\cline { 1 - 1 } & Fixed Deposit \& Saving Account & 87 & 18.8 \\
2 & Insurance Policy & 58 & 12.5 \\
3 & Public Provident Fund & 43 & 9.3 \\
4 & National saving Certificate & 34 & 7.3 \\
5 & Mutual Fund & 27 & 5.8 \\
6 & Stock Market & 12 & 5.0 \\
7 & Bond & 84 & 2.6 \\
8 & Investment in Gold \& Silver & & 18.1 \\
\hline
\end{tabular}

$-134-$ 
A Study of Investment Behaviour in relation to Middle Class Group Families towards Different Types of Opportunities

Riyazuddin

\begin{tabular}{|c|l|c|c|}
\hline 9 & Real Estate & 41 & 8.8 \\
10 & Post Office Savings Schemes & 34 & 7.3 \\
11 & Commodity Market & 16 & 3.4 \\
12 & Investing in Art & 0 & 0 \\
13 & Chit Fund & 2 & 0.4 \\
14 & Forex Market & 30 & 0.6 \\
\hline & Total & 464 & 100 \\
\hline
\end{tabular}

Source: Primary Data

The following observation may be made from the data provided in table 1.

- $18.8 \%$ investor preferred Bank Deposits, as their first choice of Investment.

- $18.1 \%$ investor chose Investment in gold and silver as a second-most excellent avenue.

- Insurance was preferred by $12.5 \%$ of respondents as the third choice for their Investment.

- Real estate, Bullions and share market are least preferred investment avenues among investors

2. The objective of Investment: - Based on the survey, many intentions create a passion for Investment to achieve these goals or motives; an investor makes Investment of his savings in different avenues, according to his choice, capacity, and risk-bearing power. These objectives can be classified into various kinds of priority such as high priority (Own property/house), long term top priority goals (For old age/retirement plan), low priority goals (Plan for visit anywhere) and to commence own concern based on the way investor approach them. The following table shows the responses of investors towards a different kind of objective

Table 2: Objectives of Investment

\begin{tabular}{|c|l|c|}
\hline S. No. & \multicolumn{1}{|c|}{ Variables } & \multicolumn{1}{|c|}{ \% of Respondents } \\
\hline 1 & Wealth Creation & $17 \%$ \\
2 & Education & $23 \%$ \\
3 & Tangible Assets Dream (Own house, Property, etc.) & $19 \%$ \\
4 & Future Uncertain need (Future diseases) & $21 \%$ \\
5 & Planning for retirement & $15 \%$ \\
6 & Others (Tour, Marriage, etc.) & $05 \%$ \\
\hline
\end{tabular}

The following observation may be made from the data provided in table 2 .

- $23 \%$ of investors invest their money for the higher education of their children.

- $21 \%$ investor invests their money for future uncertain needs or diseases or accidental loss.

- $19 \%$ of investors invest their money to fulfill their tangible dream as owning a house or car.

- $17 \%$ of investor invests their money to maximize their wealth.

- $15 \%$ investor invests their money for old age or retirement.

- $5 \%$ invest their money for marriage or tour purposes.

3. Risk Bearing Capacity: The middle-income class family could hardly save a small amount of their annual income due to the toast expenses of daily. So table 7 characterizes their riskbearing capacity as high, moderate, and low for making Investment in investment tools. 
A Study of Investment Behaviour in relation to Middle Class Group Families towards Different Types of Opportunities Riyazuddin

Table 3: Risk Bearing Capacity

\begin{tabular}{|c|l|c|}
\hline S.No. & \multicolumn{1}{|c|}{ Variables } & \% of Respondents \\
\hline 1 & High-risk taker & $05 \%$ \\
2 & Moderate risk taker & $30 \%$ \\
3 & Low-risk taker & $65 \%$ \\
\hline
\end{tabular}

Source: Primary Data

The following observation may be made from the data provided in table 7.

- $65 \%$ of investors don't want to have any risk in any investment

- $30 \%$ investment can tolerate risk at a specific limit, but

- $5 \%$ of investors can bear any type of threat at the maximum level.

4. Source of information about investment planning: Mostly decisions of investors are based on available reports through advertisement: publish data on print media or electronic media, relatives, friends, financial advisors, etc. which have been shown in the below table.

Table 4: Source of Information about Investment Planning

\begin{tabular}{|c|l|c|}
\hline S.No. & \multicolumn{1}{|c|}{ Variables } & \% of Respondents \\
\hline 1 & Financial Advisors & $10 \%$ \\
2 & By Self & $20 \%$ \\
3 & Advertisements & $25 \%$ \\
4 & Friends or Relatives & $15 \%$ \\
5 & Internet & $30 \%$ \\
\hline
\end{tabular}

Source: Primary Data

The following observations have been received from the above table.

1. $10 \%$ of investors make Investment on the advice of financial advisors.

2. $20 \%$ of investors invest by using their own decisions and $25 \%$ on advertisement basis.

3. $15 \%$ of investors invest in the advice of friends and relatives, and $30 \%$ taken data from the internet.

6. FINDINGS

1. Most investors prefer to invest in bank deposits or post office because of less risk with a fixed rate of return. It also provides a withdrawal facility whenever they required. Therefore it is more preferable for middle-class income families.

2. Silver and gold or precious metal are the second desirable investment avenue for middle-class income families as they think that this is to liquidate Investment because it can be converted into cash based on requirements.

3. Insurance is also a vital part of Investment for this group as it provides segments of policies as per investor's choice.

4. Investment or saving for the education of their children is on a priority basis.

5. The risk-bearing capacity of middle-class families is deficient; therefore, it affects the choice of investors.

6. The middle group class investment decision is affected by their friends, relatives, family members to a great extent.

7. This group also has a choice of Investment in real estate due to less risk. 
8. Share market is least preferable by the income class due to a lack of knowledge and misconception about the share market.

9. This group prefers to invest annually rather than prompt Investment.

\section{CONCLUSION \& SUGgestion}

Based on the current survey and various reports show that the Indian economy is growing, but still, it is prolonged at present. The Middle group class is getting higher per capita. But the inflation rate is also increasing at a higher rate than the increasing rate of per capita income of the lower and middle-class families. Therefore it is tough for the middle-class group to invest after deducting huge expenses of routine life. The middle-class family looks for a more safe investment avenue with very less risk-bearing capacity. That is why they always keep the fixed deposit in banks, post office, public provident fund, and life insurance policies on a priority basis. But based on the survey, they do not look satisfied with their investment choice in such investment tools due to low return. With this low, they are not able to fulfill their future needs. So it is suggested that Govt. and investment schemes maker should make schemes or policies, as per their requirements and choice, on which they may get higher returns with less risk.

Traditional investors keep sufficient knowledge about different investment tools as a post office, banks, bullions, etc. but they are aware of derivatives financial market, share market, forex market, etc. The reason is behind that these markets are full of risk, which cannot be borne. So here, this is a requirement of awareness and sufficient knowledge about these markets. The workshop, T.V. Channels programs, should be run to make aware and encourage them to invest. Free broker's facility, consultancy for Investment, and the latest happening information in the financial market should be arranged for them.

Real estate is one of the right options to invest in middle-class families, but they are not able to spend a massive amount as they have low income. Hence government and Policymakers should make policies for trouble-free housing finance with the low-interest rate on housing loans.

The middle-class family is also more interested in investing in precious metals such as gold, silver, etc. in the forms of biscuits or coins. So these types of options for investments should be promoted by banks and post offices to attract people to make investment more.

The tax benefits also come in an investor's mind to save tax. It shows the tax concessions given by the government are less attractive. Therefore, the tax benefits on long term saving for Investment are needed and should be promoted by the government and policymakers.

\section{FUTURE SCOPE OF THE STUdY}

This study is centering on the priority of Investment tools by particular income class (investigators), and it will be helpful to ascertain the better investment opportunities in the market for the income group.

\section{REFERENCES}

\section{Journal Papers}

[1]. Hosamane, D. Manjappa, and Niranjan, R (2010) "Determinants of Investment Pattern In Indian Manufacturing Industries A Panel Data Study" Indian Journal Of Economics \& Business, Vol. 9, No. 1, (2010): 207-218.

[2]. Indian income-class opportunities (2012), a report published by Gyan research and analytics Pvt. Ltd. 
A Study of Investment Behaviour in relation to Middle Class Group Families towards Different Types of Opportunities Riyazuddin

[3]. Kabra, Gaurav; Kumar, Prashant, and Dash, Kumar, Manoj (2010) "Factors Influencing Investment Decision of Generation in India: An Econometric Study" Asian Journal of Management Research ISSN2229-3795 2010.

[4]. Kaur, Mandeep, and Vohra, Tina (2012) "Understanding Individual Investor's Behavior: A Review of Empirical Evidence" Pacific Business Review International, Volume 5, Issue 6, December 2012.

[5]. Kaur, Mandeep, and Vohra, Tina (2012) "Understanding Individual Investor's Behavior: A Review of Empirical Evidence" Pacific.

[6]. Megha Goel and Dr. Anukrati Sharma, (2014) "A Study of Investment Behavior of Middle Income Group towards Different Kinds of Investment Avenues" IOSR Journal of Business and Management, Vol. 16, Issue 8, ISSN: 2319-7668.

[7]. S.C. Das and V. Kumar, (2016) "Discretionary Savings and Investment Behaviour of Middle Class "Households in India: Empirical Evidence Study" International Journal of Applied Marketing and Management, Volume 1, Issue 6 (2016).

[8]. Samudra, Arpana and Burghate, M.A.(2012) "A Study on Investment Behavior of MiddleClass Households In Nagpur" International Journal Of Social Sciences \& Interdisciplinary Research Vol.1No.5,May 2012,ISSN 22773630.

[9]. Sharma, Preeti, and Rao, D.N. (2014) "A Study of Risk Orientation of Retail Investors in Indian Mutual Fund Industry with Special Reference to Rajasthan, India" Global Journal for Research Analysis, Vol.3 / Issue: 1/Jan 2014, ISSN 22778160.

\section{Books}

[1]. Financial Freedom, Authored by Grant Sabatier.

[2]. Portfolio Management (2005) Published by ICFAI University, Hyderabad.

[3]. Security Analysis (2005) Published by ICFAI University, Hyderabad.

[4]. The Intelligent Investors (2019) Authored by Warren Buffett and Revised by Benjamin Graham.

\section{Websites}

[1]. www.yahooanswer. Com

[2]. www.wikipedia.com

[3]. www.Allbankingsolution.com

[4]. www.rbi.org

[5]. www.sgsrjournals.co.in

[6]. www.worldbank.org

[7]. www.nabard.org 